\title{
A Comparative Study Between Team Game Tournament and Direct Instruction Method in Teaching Reading
}

\author{
Ahunberdi Tashliyev, Ngadiso, Endang Setyaningsih \\ English Education Department \\ Teacher Training and Education Faculty \\ Sebelas Maret University of Surakarta
}

Email: ahunberdi@mail.ru

\begin{abstract}
The aim of this research is to find out: (1) whether there is a significant difference in reading skill between the students taught using Team Game Tournament and the students taught using Direct Instruction Method; and (2) which group of students has better reading skill, the group taught using Team Game Tournament or the group taught using Direct Instruction Method. The research method used in this study is an experimental method. This research used 20 students for the experimental group and 20 students for the control group. The research instruments used to collect the data in this study is test. The data were analyzed by using t-test formula. The computation of the data shows that: (1) there is a significant difference in reading skill between the students taught using Team Game Tournament and the students taught using Direct Instruction; and (2) Team Game Tournament is more effective than Direct Instruction Method to teach reading.
\end{abstract}

Keywords: reading, team game tournament, direct instruction method.

\section{INTRODUCTION}

Reading is one of the most important skills in daily life. People deal with reading in almost of their activities. It is because reading serves many different purposes. Reading for information, for instance, is done by many people every day. Newspaper is read by many people who want to get the latest update of the information in every single day. Another purpose of reading is reading for pleasures. Many people have declared reading as their hobby. They love reading novels, short stories, even comic books, and etc. That is why reading cannot be separated from most people's daily life.

In relation to teaching and learning process at schools, reading is done by students in almost all of their subjects, such as biology, history, and especially in English language subject. As argued by Nunan (2003: 69) reading is the most important skill to master in order to ensure success not only in learning English, but also in learning any content class where reading is required.
By having a good reading ability, students are expected to make greater progress and development in all other areas of learning.

Most of the teaching reading at schools is focused on teaching reading skill. As argued by Richards and Renandya (2002: 227), reading for comprehension is the primary purpose for reading. Therefore, students are always asked to comprehend reading texts by their teacher. In order to do that, students must have the skills and the motivation in doing reading for comprehension. In term of skills, for instance, they must be able to find the main idea of the paragraph, to understand the supporting details of the paragraph, and finally the must be able to build a comprehension about that paragraph. But that's not enough. Students are also need to be motivated and be focused in reading. They need to pay attention to the paragraph. They have to set up their mind to comprehend the paragraph and text in general. 
However, students are not motivated in reading. It can be seen in the teaching and learning of reading. Usually, students do not follow the reading lesson because they feel bored and unmotivated to read. They tend to discuss another topic in the teaching and learning of reading instead of comprehending the text. It is because during the process of reading, the students sometimes do not focus on the text. They are not motivated enough to read the text. Moreover, sometimes the topic of the text is not interesting for some of the students. It will affects to the students in comprehending the text.

Unfortunately, most of the teachers do not realize these problems. They do not make any treatment in making change of the teaching and learning of reading. Students are sometime asked to comprehend the reading texts from the textbooks. They are sometimes asked to comprehend the texts by answering the question provided. In this reading activity, students are not given the responsibility to comprehend the texts deeply. It will limit the students' attention in comprehending the reading text. By this, students will not comprehend the text optimally.

Since students often feel bored in teaching and learning of reading, it seems that they need new learning methods which are more challenging and interesting. Many research studies have been done in order to solve this problem. Many reading methods have been used to make the students active in teaching and learning of reading. TeamGame-Tournament method is one of the methods which offers challenging activities which are applicable in teaching reading comprehension.

In the Team-Game-Tournament method, students are given another way of comprehending a reading text. Here, the students are expected to work in groups.
What they need to do is not answering the question based on the reading texts as what they usually have in common reading activities. The students are expected to make some questions based on the reading text which is provided. Then, there will be a tournament between the groups. The group that makes the most difficult questions and the fastest in answering the other groups' questions will be the winner.

TGT method has been used by many teachers in the foreign country. Most of them give positive attitudes towards TGT method. Wansley (in Slavin, 1995: 85), the eighth grade teacher in Caloosa Middle School of Cape Coral Florida, said that TGT method was one of the best method she had ever used in her classroom. Furthermore, she said that TGT method allowed her as a teacher to use competition in a constructive/positive atmosphere. By this, TGT method is important to be applied in the class.

However, most Indonesian teachers use Direct Instruction Method in their teaching. Most of them are not familiar with Team-Game-Tournament method. They do not know the benefits of using the TGT method. Therefore, in this research, the researcher is trying to apply the Team Game Tournament and Direct Instruction Method to teach reading

According to Slavin (2005:170), Team Game Tournament consists of the learning activities as follows:

1. Select a instructional topic and present it to the students (e.g. Hobbies)

2. Develop a list of question on the topic. Number them. Cut out small pieces of paper and number them so that total matches the number of question that you have develop for the topic to measure understanding (e.g. if you have 35 questions, create small pieces of paper with number 1-35 on them). Give a set questions to one student in each group 
who reads the questions as their corresponding numbers are drawn from the pile.

3. Team Game - place students in heterogeneous groups of 4-5 by ability and have them review material during this "team" phase by selecting a number from the pile. Groups must be equal in size. Give each group a "Letter Identity" (e.g. Group

A) and each student a Number Identity (e.g. Student 1). Students must answer the question that matches the number they selected from the pile. For example, if student select \#22 from the pile and question \#22 is "I use racket and shuttlecock every morning. What is my hobby?," that student is challenged to answer that question. If he or she cannot come up with an answer, a teammate can "steal" the question. Teams share knowledge during this phase of the lesson (i.e. teach their teammates)

4. Tournament- place students in new groups made up of individuals from each of the "Team Review" tables (step 2) All "students $1 \mathrm{~s}$ " go to table 1 (these might be lower achieving students) while all "students $2 \mathrm{~s}$ " (higher achieving) go to Table 2. In the "Game" phase, students are placed in homogeneous groups with students of similar ability and compete against one another. For every question a student answer correctly, he or she earns a point. One person at each "tournament table" must keep scores for every individual at the "Game" table.

5. Students return to their Team Game tables and report their scores. Team scores are compared and the winning team earns a reward.

6. Students take an assessment. The scores for each Team (e.gA, B, C..) are compiled and averaged. Offer "bonus points" fir the team that earns the highest average and/or "improvement points" to the team that improves its average the most over previous assessments.

According to Joyce, Weil, and Calhoun (2000: 339), the term direct instruction refers to a pattern of teaching that consist of the teacher's explaining a new concept or skill to a large group of students, having them test their understanding by practicing under teacher direction (that is, controlled practice), and encouraging them to continue to practice under teacher guidance (guided practice). Cruickshank, Bainer, and Metcalf (1999:

223) add the basic idea of direct instruction is to get students to learn as much academic content as efficiently as possible

Peterson (in Cruickshank, Bainer, and Metcalf, 1999: 231) suggests that direct instruction is similar to "traditional teaching". Generally speaking, traditional teaching is directed toward learning academic content. It is also characterized by a teacher-centered and teacher dominated classroom. Direct instruction requires teachers to provide background information, to demostrade the skill being taught, and then to provide time for students to practice the skill and receive feedback on how they are doing (Arends, 1998: 428). In general, this is the method that teachers should use when introducing learning strategies to their students.

Furthermore, Borich (1996: 244) says Direct Instruction is synomous with expository or didactic teaching, is a teachercentered. It is a teacher method in which the teacher is the major information provider. The teacher's role is to pass facts, rules or action sequences on to students in the most direct way possible. He also adds, direct instruction usually takes the form of a lecture-recitation with explanation, examples and opportunities for practice and feedback. 
From the above reviews about Direct Instruction Method, it can be concluded that Direct Instruction Method is a pattern of teaching where the activities of teaching and learning process are under the teacher's control (teacher-centered) in which the teacher becomes the major information. In this method teacher gets the students to learn academic contents as efficiently as possible. This method covers teacher's explanation, provide time for students to practice what have they learn, and give feedback to the students.

Arends (1988: 428-429) mentions the steps of conducting Direct Instruction Method. They are:

a. Provide objectives for the lesson and establish set.

Get students' attention and explain to them that the goal of the lesson is to acquire a learning strategy that will help them learn better. Point out connections between effective use of learning strategies and performance on test.

In this first step, the teacher goes over objectives for lesson, give background information, and explains why the lesson is important. Gets students ready to learn.

b. Explain and demonstrate a particular learning strategy.

Teacher teaches the strategy to students using verbal presentation and demonstration. Explain why the strategy works, and tie new information about the strategy into what students already know about it. In demonstrating the mental processes, teacher thinks out loud with students and describes what is going on in teacher's own mind .

In this phase, the teacher distributes the learning material then presents and demonstrates learning materialstep by step in accordance with the correct sequence. The teacher teaches the studens how to find the information in the text by using reading strategy such as scanning and skimming. c. Provide opportunities for guided practice.

Do this immediately, perhaps with another student, but under your supervision.

In teaching reading, the teacher asks the students to discuss the given text with other students and asks them to answer the questions related to the text. In this step, teacher's role is to guide the students to understand the text.

d. Check for understanding and provide feedback.

Stop the practice and check to see what kinds of problems students are having with the strategy. Have students think out loud about what is going on in their mind as they use the strategy. Give them feedback on how they are doing. Carry on a discussion about the strategy.

In the fourth phase, the teacher checks students' understanding by checking the students' answer and then provide appropriate feedback.

e. Provide for independent practice and transfer.

Give students an opportunityto use the strategy independently, and then evaluate their success on practice assignments. In the last step, the teacher distributes new material then asks the students to answer the questions related to the text individually.

The result of the research shows that there is significant difference in the students' reading skill between grade $\mathrm{X}$ students of SMA N SBBS Sragen who are taught by using the Team-GameTournament method and those who are taught by using Direct Instruction Method. Moreover, Game Tournament (TGT) method is more effective than Direct Instruction Method (DIM).

\section{RESEARCH METHODS}

The method used in this research is experimental method with pretest-posttest 
and control group design. According to Burke (in Cahyaningrum, 2010: 60), Experimental design with Pretest- Posttest and Control Group is a research design that administers a post-test to an experimental group and a control group after both groups have been given a pre-test and one of the groups has been administered to the experimental treatment condition. In this research, group of research participants were divided into two groups, they were experimental group and conrol group. The experimental group was the group that received the experimental treatment condition, while the control group was the group that did not receive the experimenal treatment condition. Both groups were given pre-test on reading. After that, the experimental group was taught using Team Game Tournament while the control group was taught using Direct Instruction Method. Finally, the experimental and control groups were given post-test on reading in order to know the significant difference in reading skill between students taught using Team Game Tournament and students taught using Direct Instruction Method.

This research was conducted at the tenth grade of SMA Negeri Sragen Bilingual Boarding School in the academic year 2014/2015. The writer took two classes as the sample. Those classes were class X-B as the experimental group who were taught using Team Game Tournament and X-A as the control group who were taught using Direct Instruction Method.

The writer used t-test in analyzing the data to compare the two techniques, Team Game Tournament and Direct Instruction Method. As the prerequisite for the t-test, firstly the data have to be tested using normality and homogeneity test.

\section{RESEARCH FINDINGS AND DISCUSSIONS}

The data which were analyzed in this research are pre-test and post-test scores of the two groups, experimental group and control group. The pre-test and post-test scores of both the experimental group and the control group were compared by using ttest formula to prove whether there is significant difference between the two groups in reading skill and to find which group has higher score in reading skill.

The data of the pre-test of experimental class show that the highest score is 80 , while the lowest score is 60 , the range is 20 , the number of class is 6 , the interval is 5.2933 , the mean is 71.75 , the mode is 70.36 , the median is 70.93 , and the standard deviation is 6.12909 .

Table 1. The frequency distribution of pre-test scores of the experimental group.

\begin{tabular}{llllll}
\hline $\begin{array}{l}\text { Class } \\
\text { Limits }\end{array}$ & $\begin{array}{l}\text { Class } \\
\text { Boundaries }\end{array}$ & Midpoint & Tally & Frequency & Percentage \\
\hline $60-63$ & $59,5-63,5$ & 61.5 & II & 2 & $10 \%$ \\
$64-67$ & $63,5-67,5$ & 65.5 & II & 2 & $10 \%$ \\
$68-71$ & $67,5-71,5$ & 69.5 & WII II & 7 & $35 \%$ \\
$72-75$ & $71,5-75,5$ & 73.5 & WII & 5 & $25 \%$ \\
$76-79$ & $75,5-79,5$ & 77.5 & & 0 & $0 \%$ \\
$80-83$ & $79,5-83,5$ & 81.5 & IIII & 4 & $20 \%$ \\
\hline
\end{tabular}


The data of the pre-test of control class show that the highest score is 80 , while the lowest score is 60 , the range is 20 , the number of class is 6 , the interval is 5.2933 , the mean is 71.25 , the mode is 69.9 , the median is 70.36 , and the standard deviation is 5.59017 .

\begin{tabular}{|c|c|c|c|c|c|}
\hline $\begin{array}{l}\text { Class } \\
\text { Limits }\end{array}$ & $\begin{array}{l}\text { Class } \\
\text { Boundaries }\end{array}$ & Midpoint & Tally & Frequency & Percentage \\
\hline $60-63$ & $59,5-63,5$ & 61.5 & $\mathrm{I}$ & 1 & 5 \\
\hline $64-67$ & $63,5-67,5$ & 65.5 & IIII & 4 & 20 \\
\hline $68-71$ & $67,5-71,5$ & 69.5 & 世III & 7 & 35 \\
\hline $72-75$ & $71,5-75,5$ & 73.5 & 世 & 5 & 25 \\
\hline $76-79$ & $75,5-79,5$ & 77.5 & & 0 & 0 \\
\hline \multirow[t]{2}{*}{$80-83$} & $79,5-83,5$ & 81.5 & III & 3 & 15 \\
\hline & & & & 20 & $100 \%$ \\
\hline
\end{tabular}

As the requirement of t-test, the data needed to be tested for the normality, homogenity, and similarity. The data must be normal and homogenous in post test scores. The normality testing used in this research is Liliefors testing at the level of significance of $0.05(\alpha=0.05)$, while the homogeneity testing used Bartlet formula at the level of significance of $0.05(\alpha=0.05)$.

Table 3. The result of normality test for the experimental and control groups.

\begin{tabular}{ccccccc}
\hline No & Teaching Method & $\begin{array}{c}\text { Number of } \\
\text { Sample }\end{array}$ & df & \multicolumn{2}{c}{ L. Value } & Conclusion \\
\hline 1 & $\begin{array}{c}\text { Team Game } \\
\text { Tournament }\end{array}$ & 20 & 19 & 0.1641 & 0.1900 & Normal \\
2 & $\begin{array}{c}\text { Direct Instruction } \\
\text { Method }\end{array}$ & 20 & 19 & 0.1871 & 0.1900 & Normal \\
\hline
\end{tabular}

From the data above, it can be seen that the data of both experimental group and control group are in normal distribution. In the data of the experimental group, it can be seen that $\mathrm{L}_{0}$ is 0.1641 . It is then consulted with $\mathrm{L}$ table for $\mathrm{n}=20$ at the level of significance of $0.05(\alpha=0.05)=0.1900$. Because the value of $\mathrm{L}_{\mathrm{o}}$ is lower than $\mathrm{L}_{\mathrm{t}}\left(\mathrm{L}_{\mathrm{o}}\right.$ $<\mathrm{L}_{\mathrm{t}}$ ), it can be concluded that the data of the experimental group are in normal distribution.

Meanwhile, the data of the control group show that $\mathrm{L}_{\mathrm{o}}$ is 0.1871 . It is then

The sample used in this research should come from the same level of population and have no significant consulted with $\mathrm{L}$ table for $\mathrm{n}=20$ at the level of significance of $0.05(\alpha=0.05)=0.1336$. Because the value of $\mathrm{L}_{\mathrm{o}}$ is lower than $\mathrm{L}_{\mathrm{t}}\left(\mathrm{L}_{\mathrm{o}}\right.$ $<\mathrm{L}_{\mathrm{t}}$ ), it can be concluded that the data of the control group are in normal distribution.

The homogeity testing that is used in this research is Bartlet formula. From the computation of homogeneity test of pre-test (in appendix 6), it can be seen that $\chi^{2}=$ 0.1577 is lower than $\chi_{t}^{2}=3.841$ or $\chi^{2}<\chi_{t}^{2}$. Because $\chi^{2}$ is lower than $\chi_{\mathrm{t}^{2}}$, it can be concluded that the data are homogeneous.

difference in the reading skill. To prove that the two groups have no significant difference, the researcher used the t-test. 
Null hypothesis $\left(\mathrm{H}_{\mathrm{o}}\right)$ states that there is no significant difference in the reading skill between the two classes, while the Alternative hypothesis $\left(\mathrm{H}_{\mathrm{a}}\right)$ states that there is a significant difference in reading skill between the two classes. Null hypothesis $\left(\mathrm{H}_{\mathrm{o}}\right)$ is rejected if $t_{\mathrm{o}}>t_{t}\left(\mathrm{t}_{\text {observation }}>\mathrm{t}_{\text {table }}\right)$ for degree of freedom $d f=\mathrm{n}_{1}+\mathrm{n}_{2}-2$ and the level of significance $\alpha=0.05$. On the contrary, if $t_{o}<t_{t}\left(\mathrm{t}_{\text {observation }}<\mathrm{t}_{\text {table }}\right), \mathrm{H}_{\mathrm{O}}$ is accepted.

The result of computation (t-test) shows that the $t_{\text {observation }}\left(t_{o}\right)$ is 0.2695 while the $t_{\text {table }}\left(t_{t}\right)$ for the degree of freedom 38 and the level of significance $\alpha=0.05$ is 2.0244 .
It can be seen that the $t_{\text {observation }}\left(t_{0}\right)$ is lower than the $\mathrm{t}_{\text {table }}\left(\mathrm{t}_{\mathrm{t}}\right)$, which means that the null hypotesis $\left(\mathrm{H}_{\mathrm{o}}\right)$ is accepted. It can be concluded that there is no significant difference in reading skill between the two classes (the computation can be seen in appendix 7).

The data of the post-test of experimental group show that the highest score is 95 , while the lowest score is 65 , the range is 30 , the number of class is 6 , the interval is 5.2933 , the mean is 81.25 , the mode is 79.5 , the median is 82.5 , and the standard deviation is 8.25179 .

Tabel 4. The frequency distribution of post-test scores of the experimrntal group.

\begin{tabular}{llllll}
\hline Class Limits & $\begin{array}{l}\text { Class } \\
\text { Boundaries }\end{array}$ & Midpoint & Tally & Frequency & Percentage \\
\hline $65-69$ & $64.5-69.5$ & 67 & I & 1 & $5 \%$ \\
$70-74$ & $69.5-74.5$ & 72 & I & 1 & $5 \%$ \\
$75-79$ & $74.5-79.5$ & 77 & III & $\mathbf{5}$ & $25 \%$ \\
$80-84$ & $79.5-84.5$ & 82 & III & $\mathbf{5}$ & $25 \%$ \\
$85-89$ & $84.5-89.5$ & 87 & IIII & 4 & $20 \%$ \\
$90-94$ & $89.5-94.5$ & 92 & IIII & 4 & $20 \%$
\end{tabular}

The data of the post-test control 5.2933, the mean is 72.75 , the mode is group show that the highest score is 90 , while the lowest score is 60 , the range is 30 , 73.0715 , the median is 73.7855 , and the the number of class is 6 , the interval is

Tabel 5 : The frequency distribution of post-test scores of the control group.

\begin{tabular}{llllll}
\hline Class Limits & $\begin{array}{l}\text { Class } \\
\text { Boundaries }\end{array}$ & Midpoint & Tally & Frequency & Percentage \\
\hline $65-69$ & $64.5-69.5$ & 67 & I & 1 & $5 \%$ \\
$70-74$ & $69.5-74.5$ & 72 & I & 1 & $5 \%$ \\
$75-79$ & $74.5-79.5$ & 77 & III & $\mathbf{5}$ & $25 \%$ \\
$80-84$ & $79.5-84.5$ & 82 & III & $\mathbf{5}$ & $25 \%$ \\
$85-89$ & $84.5-89.5$ & 87 & IIII & 4 & $20 \%$ \\
$90-94$ & $89.5-94.5$ & 92 & IIII & 4 & $20 \%$ \\
& & & & & \\
\hline
\end{tabular}


Table $6:$ The result of normality test for the experimental and control groups.

\begin{tabular}{|l|l|l|l|l|l|l|}
\hline No & Teaching Method & $\begin{array}{l}\text { Number of } \\
\text { Sample }\end{array}$ & df & \multicolumn{2}{|l|}{$\mathbf{L}$. Value } & Conclusion \\
\cline { 5 - 6 } & $\mathbf{L}_{\mathbf{o}}$ & $\mathbf{L}_{\mathbf{t}}$ & \\
\hline $\begin{array}{l}1 \\
\text { post- } \\
\text { test }\end{array}$ & $\begin{array}{l}\text { Team Game } \\
\text { Tournament }\end{array}$ & 20 & 19 & 0.1641 & 0.1900 & Normal \\
\hline 2 & $\begin{array}{l}\text { Direct Instruction } \\
\text { Method }\end{array}$ & 20 & 19 & 0.1871 & 0.1900 & Normal \\
\hline
\end{tabular}

The result of normality test of post-test can be seen in the table above. From the data above, it can be seen that the data of both experimental group and control group are in normal distribution. In the data of the experimental group, it can be seen that $\mathrm{L}_{\mathrm{o}}$ is 0.1641. It is then consulted with $\mathrm{L}$ table for $\mathrm{n}=20$ at the level of significance of $0.05(\alpha$ $=0.05)=0.1900$. Because the value of $\mathrm{L}_{0}$ is lower than $\mathrm{L}_{\mathrm{t}}\left(\mathrm{L}_{\mathrm{o}}<\mathrm{L}_{\mathrm{t}}\right)$, it can be concluded that the data of the experimental group are in normal distribution.

Meanwhile, the data of the control group show that $\mathrm{L}_{\mathrm{o}}$ is 0.1871 . It is then consulted with $\mathrm{L}$ table for $\mathrm{n}=20$ at the level of significance of $0.05(\alpha=0.05)=0.1336$. Because the value of $\mathrm{L}_{\mathrm{o}}$ is lower than $\mathrm{L}_{\mathrm{t}}\left(\mathrm{L}_{\mathrm{o}}\right.$ $<\mathrm{L}_{\mathrm{t}}$ ), it can be concluded that the data of the control group are in normal distribution.

From the computation of homogeneity test of post-test (in appendix 6 ), it can be seen that $\chi^{2}=0.1577$ is lower than $\chi_{\mathrm{t}^{2}}{ }^{2} 3.841$ or $\chi^{2}<\chi_{\mathrm{t}^{2}}$. Because $\chi^{2}$ is lower than $\chi_{\mathrm{t}^{2}}$, it can be concluded that the data are homogeneous.

After finding out the result of the prerequisite tests, the writer then calculated the t-test to test the first hypothesis. To test whether the first hypothesis is accepted or not, the writer used t-test formula. The data which are analyzed in this research are posttest scores of the two groups, the experimental group and the control group.

Null hypothesis $\left(\mathrm{H}_{\mathrm{o}}\right)$ states that there is no significant difference in the reading skill between the two classes, while the Alternative hypothesis $\left(\mathrm{H}_{\mathrm{a}}\right)$ states that there is a significant difference in reading skill between the two classes. Null hypothesis $\left(\mathrm{H}_{\mathrm{o}}\right)$ is rejected if $t_{\mathrm{o}}>t_{t}\left(\mathrm{t}_{\mathrm{observation}}>\mathrm{t}_{\text {table }}\right)$ for degree of freedom $d f=\mathrm{n}_{1}+\mathrm{n}_{2}-2$ and the level of significance $\alpha=0.05$. On the contrary, if $t_{o}<t_{t}\left(\mathrm{t}_{\mathrm{observation}}<\mathrm{t}_{\text {table }}\right), \mathrm{H}_{\mathrm{O}}$ is accepted.

The result of computation (t-test) shows that the $t_{\text {observation }}\left(t_{o}\right)$ is 3.3022 while the $t_{\text {table }}\left(t_{t}\right)$ for the degree of freedom 38 and the level of significance $\alpha=0.05$ is 2.0244 . It can be seen that the $t_{\text {observation }}\left(t_{0}\right)$ is higher than the $t_{\text {table }}\left(t_{t}\right)$, which means that the null hypotesis $\left(\mathrm{H}_{\mathrm{o}}\right)$ is rejected. It can be concluded that there is no significant difference in reading skill between the two classes.

Thus, it can be concluded that there is a significant difference in reading skill between students taught by using Team Game Tournament and students taught by using Direct Instruction Method.

The second hypothesis of this research is that the students taught by using Team Game Tournament Method has a better reading skill than the students taught by using Direct Instruction Method. In this case, to test the second hypothesis, the writer needs to compare the post-test mean scores of the two groups. The mean of the scores of the experimental group is 81.25, while the mean of the scores of control group is 72.75. The mean difference between them is 8.5 . It can be concluded that the group taught by using Team Game Tournament Method has a better reading skill than the group taught by using Direct 
Instruction Method. In other words, Team Game Tournament Method is more effective than Direct Instruction Method to teach reading.

The result of the research shows that there is a significant difference in reading skill between the students taught using Team Game Tournament Method and the students taught using Direct Instruction Method Team Game Tournament Method is more effective than Direct Instruction Method to teach reading.

TGT emphasizes that students must be active in teaching and learning process. Students learn in small teams activities formed by teacher, where each team (which consists of four persons with different abilities) has the same aim to tackle the problem given by teacher. When they are in teams, they cooperate and share the knowledge so they can contribute the best score for their teams. These are what Arends (2007: 8-9) says that cooperative learning (where TGT comes from) gives three effects: (1) students cooperative rather than compete; (2) students have better relationship; (3) students have better achievement.

On the contrary, in Direct Instruction Method, the students are the objects of learning. They are passive students rather than active since they fully depend on the teacher's instruction and guidance, they listen to the teacher's instruction and do the things required by the teacher. The activity in Direct Instruction Method is teachercentered that makes the students have lack opportunities in the class to share their own opinions, because in teaching and learning process the students just depend on the teacher's direction. It makes the students become passive in learning process.

As stated by Joyce, Weil, and Calhoun (2000: 339), Direct Instruction is a pattern of teaching that consist of the teacher's explaining new concept or skill to a large group of the students, having them test their understanding by practicing under teacher's direction (that is, controlled practice), and encouraging them to continue to practice under teacher's guidance (guided practice). Based on the result of the research, the computation of the t-test shows that $t_{0}=3.3022$ is higher than $t_{t}(38,0.05)=$ 2.0244. It means that there is a significant difference in reading skill between students taught using Team Game Tournament and students taught using Direct Instruction Method. This can be explained by the following reasons.

Moreover, the students taught using Team Game Tournament has a better reading skill than those taught using Direct Instruction Method. The mean of scores of the experimental group is 81.25 , while the mean of the score of control grop is 72.75 . The difference between them is 8.5. It means that the mean of scores of the experimental group is higher than the mean of scores of the control group. In other words, the students taught using Team Game Tournament has a better reading skill than those taught using Direct Instruction Method.

The explanation above recomends the result of this research that there is a significant difference in reading skill between the students taught using Team Game Tournament and the students taught using Direct Instruction Method. In other words, teaching reading by using Team Game Tournament is more effective than teaching reading by using Direct Instruction Method. 


\section{CONCLUSIONS AND SUGGESTIONS}

Based on the result of the research, it conclusions are there is a significant difference in reading skill between the students taught using Team Game Tournament and the students taught using Direct Instruction Method to the twelfth grade students of SMA Negeri Sragen Bilingual Boarding School at the academic year of 20014/2015 and Team Game Tournament is more effective to be applied in teaching reading than Direct Instruction Method to the tenth grade students of SMA Negeri Sragen Bilingual Boarding School at the academic year of 20014/2015.

Having concluded the result of the research, the writer would like to propose some suggestions. For English teachers, teachers are suggested to apply Team Game Tournament in teaching reading in order that the students' skill in reading can improve. To English students, they should be active in the teaching learning process and do more practices in the class. In Team Game Tournament, they should be able to work in heterogeneous groups, not only with the group whom they like. Students should respect others' opinions and use the time well when they discuss in groups. Besides, they have to improve their reading skill with various activities. To other researchers, the writer hopes that this method can be applied by other researcher in the other skills, such as listening, speaking, reading, and writing and other level of students. Considering that this research still has any lack, the writer hopes that the other researchers can use the result of this research as the references for further research.

\section{BIBLIOGRAPHY}

Arends, Richard I. 1998. Learning to Teach Fourt Edition. Boston: The McGrawHill Company, Inc.

Borich, Gary D. 1996. Effective Teaching Methods Third Edition. New Jersey: Prentice-Hall, Inc.

Cruickshank, Donald R. Bainer, Deborah L. Metcalf, Kim K. 1999. The Act of Teaching Second Edition. Boston: McGraw-Hill College.

Cahyaningrum, Dewi. 2010. The effectiveness of using video in teaching listening of oral narrative text. Unpublished Thesis. Sebelas Maret University of Surakarta

Nunan, D. 2003. Practical English language Teaching. New York: McGraw Hill Contemporary.

Slavin, E. Robert. 1995. Cooperative Learning. United States of America

Joyce, Bruce. Weil, Marsha. Calhoun, Emily. 2000. Models of Teaching. Boston: Allyn and Bacon 